\title{
Hațhayoga's Floruit on the Eve of Colonialism
}

\author{
Jason Birch
}

My doctoral thesis (Birch 2013), which was supervised by Alexis Sanderson at the University of Oxford, contained a survey of texts on Hatha- and Rājayoga. One of the challenges of completing such a survey was that very few of the texts composed from the sixteenth to eighteenth century had been critically edited or studied academically. Inspired by several exemplary surveys of Śaiva literature in Sanderson's articles (e.g. 2001, 2007 and 2014), I visited a large number of libraries in India in an effort to consult manuscripts of unpublished yoga texts. By the end of my doctorate, it was apparent to me that yoga texts composed on the eve of colonialism provided new insights into the history of yoga and, more specifically, are crucial for understanding how Hațhayoga changed after it had been codified by Svātmārāma in the Hațhapradīpikā (circa mid-fifteenth century). In fact, after Svātmārāma had successfully transformed Haṭhayoga from an auxiliary practice into a complete soteriological system, there began what might be considered the floruit of Hathayoga, insofar as its literature flourished, its systems of practice accumulated more techniques and it became, particularly in scholarly compendiums on yoga, almost synonymous with the auxiliaries of āsana and prānāyāma.

Building on my doctoral research, this article aims to provide a framework for examining the textual sources of Hathayoga that were composed from the sixteenth to eighteenth century. After a brief summary of the early literature of Hathayoga, I shall discuss some of the salient features of the late literature by dividing the texts into two etic categories; 'extended works' and 'compendiums.' The extended works expatiate on Hathayoga as it was formulated in the Hathapradipikā, whereas the compendiums integrate teachings of Haṭhayoga within a discourse on yoga more broadly conceived. Both categories include scholarly and practical works which, when read together in this way, reveal significant changes to both practical and theoretical conceptions of Hathayoga. Such a reading also illuminates several developments of this time that foreshadowed, and in some cases inspired, the transnational yogas of the twentieth century. The article concludes with a brief discussion on the regional extent of the literature on Hathayoga during this period and how the codification of its praxis and theory appears to have diverged in different regions. 
The earliest references to the term hațhayoga are found in some Buddhist Tantras, most notably the Guhyasamäjatantra and the Kälacakratantra, which date to the eighth and eleventh centuries, respectively, and mention it as a method of last resort when the primary techniques of these traditions had failed (Birch 2011, 541-542). An eleventh-century commentary on the Kälacakratantra, called the Vimalaprabhä, explains the term hațayoga as the name of a type of yoga that forces prāna ('vitality') into the central channel through a practice involving $n \bar{a} d a$ ('internal resonance') and retention of bindu ('generative fluids'). The earliest known Śaiva work to teach Hathayoga is the circa twelfth-century Amaraughaprabodha (Birch 2019). Its Hațhayoga is somewhat consistent with that of the Kālacakra tradition insofar as both are auxiliary practices that induce nāda. Nonetheless, a much closer counterpart to the Amaraughaprabodha's Hațhayoga exists in an eleventh-century Vajrayāna work called the Amrtasiddhi (Mallinson 2020). Both have similar accounts of three complex mudrās and a system of sounds (nāda), blisses (ānanda) and voids (śünya). It is important to note that the author of the Amrtasiddhi does not identify its yoga as Hathayoga. The reason for this is not stated in the text, but Hathayoga appears to have been a controversial practice among some Buddhist exegetes, ${ }^{1}$ and it is also possible that Hathayoga, or at the very least some of its techniques of that time, had older associations with other religious traditions. $^{2}$

Unlike earlier Buddhist works, Hațhayoga in the Amaraughaprabodha is embedded in a fourfold hierarchy in which Rajjayoga is the principal yoga. Rajjayoga is defined as the absence of mental activity, ${ }^{3}$ a meditative state that was known by this name in other Śaiva yoga texts of the same era. ${ }^{4}$ In this hierarchy, Hațhayoga was not the sole means to Rajjayoga, because the latter could also be achieved by Mantra- and Layayoga. Judging by later works, such

1 On Maitreyanātha's and Rāmapāla's rejection of Haṭhayoga, see Isaacson and Sferra 2014, and Mallinson, forthcoming 2020 .

2 On the prehistory of certain techniques which were integrated into Hațhayoga, see Mallinson 2016, 120-122. In the case of the three physical techniques taught in the Amrtasiddhi and the Amaraughaprabodha, it seems possible to me that the Amaraughaprabodha may have borrowed from a source that was older than the Amrtasiddhi (Birch 2019, 964-966) and that the physical practices themselves were not the preserve of esoteric Buddhists.

3 Amaraughaprabodha 3 d (yaś cittavrttirahitah sa tu rājayogah).

4 The earliest work to teach Rajjayoga by name is the Amanaska, which can be dated to the eleventh or early twelfth century (Birch 2014, 406-409). In nearly all texts that teach Hațhayoga, Rājayoga is mentioned as the goal of Haṭhayoga. 
as the Śivasamnhitā (5.13-28), which explain the rationale behind this hierarchy, it appears that the characteristics of the student were the basis for determining which yoga was taught to an individual, and it seems likely that Mantra-, Layaand Hathayoga were superfluous to students of extraordinary capability who could achieve Rajjayoga without an auxiliary practice. ${ }^{5}$

The praxis common to both the yoga of the Amrtasiddhi and the Hathayoga of the Amaraughaprabodha is three techniques called mahāmudrā, mahābandha and mahāvedha. A repertoire larger than this rudimentary one appears in all systems of Hathayoga that followed, such as that of the Dattatreyayogaśāstra (circa 13th-century), a Vaiṣnava work in which a collection of ten $m u d r a \bar{s}$, referred to as the Hațhayoga of Kapila, was integrated with a Vaișnava form of aștāngayoga attributed to Yājñavalkya. ${ }^{6}$ Kapila's collection of mudrās consists of khecarī, viparitakarañi, the three bandha ("locks"), and three variations of vajrolimudrā, in addition to mahāmudrā, mahābandha and mahāvedha. Combinations of some of these mudrās appear in contemporary Śaiva works, such as the Yogatārāvalī and the Yogabija, ${ }^{7}$ which teach basic systems of Hațhayoga. The latter text is known for its definition of Hațhayoga as the union of the sun and moon, which are represented by the syllables $h a$ and tha, respectively. This definition is absent from the earliest recension of the Yogabija, which simply defined Hathayoga as forcefully consuming the gross elements of the body. ${ }^{8}$

Some of the mudrās in the Dattātreyayogaśāstra also appear in systems of yoga of the same era that were not called Hathayoga as evinced, for example,

5 The Dattātreyayogaśāstra (14) states that Mantrayoga is for the lowest type of practitioner, who has a weak intellect. This is why it is the lowest yoga of the hierarchy (alpabuddhir imam yogam sevate sādhakādhamah | mantrayogo hy ayam prokto yogānām adhamas smṛtah ||). A passage in the long recension of the Amaraughaprabodha (17cd-24), which might postdate the Hathapradipikā, explicitly connects each of the four types of student to one of these four yogas. Both this passage and the similar one in the Sivasamnitā, mentioned above, appear to have been inspired by the Amrtasiddhi's discourse (chapters $15^{-18}$ ) on the four types of student in relation to the four stages of yoga.

6 This Vaișnava form of aștāangayoga is taught (without the Hațhayogic mudrās) in the Vasișțhasamnitā and Yogayājñavalkya, which were probably composed in the twelfth and fourteenth centuries, respectively.

7 Recent work on nineteen manuscripts of the Yogabija by the Hațha Yoga Project has revealed an early recension that does not teach these bandhas and mudrās. Nonetheless, it is likely that a section on four kumbhakas and the three bandhas was added to the text before the time of the Hațhapradīpikā, in an attempt to explain the practice of śakticālana and Hațhayoga.

8 Yogabïja, ms. no. 29917, f. 11v, line 5 (hațhena grasyate jädyam hațhayogah sa ucyate). The "union of the sun and moon" definition was added to later recensions of the Yogabija, one of which may still predate the Hațhapradipikā. 
by two Śaiva works, the Vivekamārtanda and the Gorakșaśataka. ${ }^{9}$ This suggests that from the twelfth to the fifteenth century the practice of these particular mudrās was more widespread than the use of the term hathayoga for designating a system of praxis. In fact, according to the available evidence, hathayoga is used in this sense in only four non-Buddhist Sanskrit yoga texts that are likely to predate the Hathapradipika $\bar{a}$, and two others whose dating is less certain. ${ }^{10}$

Unlike the asceticism and yoga of esoteric traditions, the texts of Hathayoga do not mention the need for initiation $(d \bar{\imath} k s p \bar{a})$ for its practice, a characteristic that appears to reflect hațhayoga's role as an auxiliary practice for people of various religions and social status, including householders (Birch 2015, 8-10). Although some of the distinguishing mudrās of Hațhayoga, such as inverting the body, may be similar to techniques of older traditions of asceticism (tapas), the mudrās had been adapted and repurposed by tantric Buddhist and Śaiva sects by the time texts such as the Amrtasiddhi and the Amaraughaprabodha were composed. None of the early teachings on Hathayoga refer to tapas and, in contrast to the mortifying effects of extreme methods of tapas, the proponents of Hathayoga claimed that this type of yoga would not afflict the body and would, in fact, bring about health and jivanmukti ("liberation-in-life") relatively quickly. Nonetheless, in this period there were opponents to Haṭhayoga

$9 \quad$ One might also include the Śivasamphitā as an example here. The fourth chapter of this work teaches āsanas, prānāyāma and ten $m u d r a \bar{s}$, as well as yonimudrā, which became an integral part of the typology of the Hațhapradīpikā. Chapters 1-4 of the Śivasamhitā, in which these techniques are taught, do not refer to Hathayoga, which is mentioned only briefly in the fifth chapter. The first four chapters may have been an original text that was combined with the fifth sometime before the seventeenth century (Birch 2018, 107 note 13).

10 These are the Amaraughaprabodha, the Dattātreyayogaśāstra, the Yogabīja and the Yogatārāvalī. The other two are the Śivasamhitā and the Aparokșānubhūti, whose verses on Hațhayoga may not predate the Hațhapradīpikā. On the dating of the Śivasamnhitā, see Birch 2018, 107, note 13. As far as I know, the date of the Aparokșānubhüti is uncertain and it is possible that its verses on Hațhayoga were added more recently (Birch 2011, 540, notes $98-100)$. A Sanskrit Vīraśaiva work called the Śaivaratnākara by Jyotirnātha mentions in passing the four yogas in the same order as the Yogabija (i.e., Mantra, Hața-, Laya and Rājayoga). According to Elaine Fisher (personal communication, 10 March 2019), the Śaivaratnäkara may have been composed in the late-thirteenth or early-fourteenth century, which so happens to be the likely date of the early recension of the Yogabija. A large Sanskrit compendium called the Śärnigadharapaddhati, probably dated to $1363 \mathrm{CE}$, mentions Hathayoga in a syncretic section on yoga that borrows from earlier yoga texts. I am also aware of a Marathi text on yoga that may predate the fifteenth century, namely, the Vivekadarpana. This work defines but rejects Hațhayoga in favour of a gnostic type of Rājayoga. I would like to thank James Mallinson for drawing my attention to the Vivekadarpaṇa and Elaine Fisher for the Śaivaratnākara. 
who considered it to be like hard asceticism insofar as it was a cause of suffering and unnecessary exertion. These opponents usually favoured effortless gnostic methods for attaining liberation. ${ }^{11}$

The conception of Hațhayoga in the Hațapradīpikā represents a turning point in its history. The author of this work Svātmārāma incorporated a larger repertoire of techniques than earlier works and synthesized diverse teachings of various yoga traditions into a cohesive system, which he called Hațhayoga. Before Svātmārāma's efforts, Hațhayoga had been conceived as one of several auxiliaries in hierarchical models of yoga. In the Hațapradipikā, Hațhayoga is the sole means to Rajayoga and a complete soteriological system. The success of Svātmārāma's interpretation is attested by the fact that subsequent authors borrowed much of the structure and content of the Hathapradīpika in creating more extensive works on Hațhayoga. Also, the Hațhapradīpikā was widely quoted as an authority on its subject, in particular by erudite authors of compendiums on yoga that were composed after the fifteenth century, and it appears to have spread throughout most of India. Recently published catalogues indicate that nearly two hundred manuscripts of the Hathapradīpika are held in libraries throughout India, from Kashmir to Tamil Nadu and Gujarat to West Bengal in various scripts, as well as a few vernacular commentaries.

The Hațapradipika might be considered the culmination of a formative period in the development of Hathayoga as a system of praxis. In this sense, it marks the beginning of Hathayoga as a distinct method that combined both seated and non-seated āsanas, the eight kumbhakas and the ten mudrās. In keeping with the earlier literature, the main goal of these techniques was Rājayoga. However, in addition to the mudrās of Hațhayoga, Svātmārāma also stipulated the practice of three other mudrās for Rājayoga, namely, śämbhavi mudrā, khecarimudra $\bar{a}^{12}$ and a simplified form of șaṇmukhimudrā, which is not named as such, but is prescribed for "fusing the mind with the internal resonance" (nādānusandhāna). ${ }^{13}$ These "meditational" mudrās probably derive

11 Early examples of texts that critique and reject Hathayoga and its methods include the Mokșopāya/Laghuyogavāsiștha and the Amanaska (Birch 2011, 531, 544-545).

12 Khecarimudrā is taught in chapters three and four of the Hațhapradīpikā. In the fourth chapter, the practice of this mudrā consists of focusing the mind between the eyebrows, rather than the Hațhayogic khecarimudrā of inserting the tongue into the nasopharyngeal cavity, which is taught in the third chapter.

13 The Hațhapradīpika (4.68) states that the ears, eyes, nostrils and mouth should be blocked in order to hear the internal resonance (nāda) in the sușumnā channel. Brahmānanda's Jyotsnā commentary on this verse adds that the senses are blocked by the fingers, and he calls this practice șaṇmukhimudrā. A simpler technique is also mentioned at Hațhapradīpikā 4.82ab, in which the yogin presses the ears with the hands to initiate nādānu- 
from older traditions of Rājayoga, one of which explicitly rejects the mudrās of Hațhayoga. ${ }^{14}$ Their inclusion in the Hațhapradīpikā reflects Svātmārāma's efforts to bring together techniques of diverse traditions under the umbrella term hațayoga.

After the fifteenth century, the composition of yoga texts which teach or integrate Hathayoga flourished. Although these texts reveal significant efforts at augmenting Hathayoga's repertoire of techniques and synthesising it with other yogas, religions and philosophies, the schema of the Hathapradipikā was most often the starting point and, in many cases, the prevailing paradigm for Hațhayoga in both the scholarly and more praxis-orientated works that will be discussed below.

Post Fifteenth-Century Literature of Hațhayoga

A notable change in the literature that followed the Hațapradipika was the composition of more comprehensive works on Hathayoga and large compendiums on yoga that integrated Hațhayoga. The early literature on Haṭhayoga consists mainly of short pithy texts that provide skeletal systems of practice and rudimentary theoretical details. The later literature incorporates more techniques and theory, as well as more elaborate systems of practice. The considerable growth in the length of the later works can be seen in Table 19.1.

It should be noted that, on the whole, the early works were composed in a low register of Sanskrit and anuștubh metre..$^{15}$ They are prescriptive and elementary, which suggests that they were probably written for practitioners. In contrast to this, many of the later works, such as the Hațatattvakaumudi and the Yogacintämani, are more scholarly and tend to be written in higher registers of Sanskrit. Their authors utilize more complex metres, compile their material from a wider range of sources and often include commentary on the older sources, which are frequently cited with attribution.

sandhāna (karnau pidhāya hastābhyām yaḥ șrṇoti dhvaniṃ munị̣). A similar technique is described in the Śivasvarodaya (383), the Rājayogämṛtasāra of Ānandānandanātha (1.1718, f. 9r-9v), the Maṇdalabrähmaṇopanișat (2.2.2) and the Jogapradīpyakā (685-688), and it is depicted in an illustrated manuscript called "seven assanas of yoga" at the National Museum of New Delhi, PCwA gallery.

14 For example, one of the earliest yoga texts to teach a mudrā called śambhavī is the Amanaska, a text on Rājayoga that explicitly rejects prānāāamma and the mudrās and karanas associated with it (Birch 2014, 406-408).

15 The exception is the Yogatārāvalī, which is composed in triștubh and incorporates poetic images, etc. 
TABLE 19.1 A comparison of the number of verses in early and late texts on Haṭhayoga

\begin{tabular}{|c|c|c|}
\hline & Texts on Hațhayoga & No. of verses \\
\hline \multirow[t]{5}{*}{ Pre-16th c. texts } & Yogatārāvalī (14th c.) & 29 \\
\hline & Amaraughaprabodha (12th c.) & $46^{\mathrm{a}}$ \\
\hline & Dattātreyayogaśāstra (13th c.) & 169 \\
\hline & Yogabija (14th c.) & 170 \\
\hline & Haṭhapradīpikā (15th c.) & 392 \\
\hline \multirow[t]{5}{*}{ Post-16th c. texts } & Hațharatnāvalī (17th c.) & 404 \\
\hline & Hațhapradīpikā, 10 chs (18th c.) & 595 \\
\hline & Siddhāntamuktāvalī (18th c.) & $1553^{\mathrm{b}}$ \\
\hline & Hațhatattvakaumudī (18th c.) & $1680^{c}$ \\
\hline & Yogacintāmaṇi (17th c.) & $3423^{\mathrm{d}}$ \\
\hline
\end{tabular}

a This number of verses is based on a short recension of the Amaraughaprabodha, which is older than the recension published by Mallik (1954). The short recension is preserved by two manuscripts (Ms. No. 1448 at the Government Oriental Manuscript Library, University of Madras, Chennai, and Ms. No. 70528 at the Adyar Library and Research Centre, Chennai). For more information on this short recension, see Birch 2019.

b This estimate is given by Gharote, et al. 2006, xvi.

c This is an approximate number of ślokas for the Hathatattvakaumudī, which has fifty-six chapters, ranging from 5 to 150 ślokas each. Most are around 20. So, I have taken an average of 30 . The Hațatattvakaumudī is undoubtedly a large yoga text, and I have felt no the need to add up all of its ślokas to prove this point.

d This estimate is given in a scribal comment at the end of a manuscript of the Yogacintāmani held at the Kaivalyadhama Yoga Institute (ms. No. 9785 p. 257, line 14).

In order to discuss the salient characteristics of the late literature on Hathayoga, I shall divide the texts into two categories. The first consists of "extended works" on the topic of Hathayoga and the second, "compendiums" that borrow from Hațha- and Rājayoga texts. There are some texts, such as the Hațhasanketacandrika $\bar{a}$, which could be placed in either category. Nonetheless, the purpose of introducing these etic categories is to reveal particular stylistic features and content that are characteristic of the works in each group.

\section{1 $\quad$ Extended Works}

The extended works expatiate on the type of Hathayoga that was outlined in the Hațhapradipikā. Many of these works borrow verses from the Hațhapradi$p i k \bar{a}$ and their discourse centres on the praxis and theory of Hațhayoga. Examples include: 


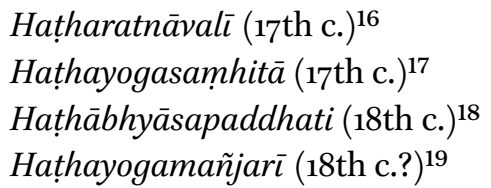

16 On the date of the Hatharatnāvalī, see Birch 2018, 109 note 24.

17 The Hațhayogasamhita is a compilation that borrows extensively from the Hathapradipikā. The opening verses (1.2-3) acknowledge the seven sages, namely Mārkaṇdeya, Bharadvāja, Marīci, Jaimini, Parāśara, Bhṛgu and Viśvāmitra, for spreading Hațhayoga in the world. The stated aim of Hațhayoga is to achieve purification (śodhanam), firmness (dṛ̂hatā), steadiness (sthairya), constancy (dhairya), lightness (läghava), direct perception ( pratyakșa) and liberation (nirlipta) of the body (ghața). Its Hațhayoga has seven auxiliaries: the șațkarma, āsana, mudrā, pratyāhāra, prāṇasamyāma, dhyāna and samādhi. The Hațhayogasamnhitā appears to have been the basis of the Gherandasamhitā (eighteenth century), which adds a new frame story (viz., a dialogue between the teacher Gheraṇ̣a and a student Caṇ̣akāpāli), several elaborate visualization practices and a six-fold Rājayoga. The Gheraṇdasam hitā calls its yoga ghațasthayoga, omits the Hațayogasamnhitā's teachings on vajrolī and redefines this mudrā as a handstand, thus revealing a reluctance to adopt the transgressive practices of Hațhayoga.

18 The terminus ad quem of the Hațābhyāsapaddhati is the Sritattvanidhi, which was a compendium composed by Kṛṣnarāja Waḍiyar III, the Mahārāja of Mysore, who was active in the mid-nineteenth century (Sjoman 1996, 40). The Hațāabyāsapaddhati was a source text of the Śïtattvanidhi (see Birch 2018, 131-134), and probably predates it by a hundred years or so (Birch and Singleton 2019, 14-16).

19 Not much scholarly attention has been given to this work. Its name in the published edition is not entirely certain according to the colophons. The text begins with the heading Hațhayogamañjarī. However, the second chapter's colophon refers to the Jogi-cintāmaṇi of Śrīsahajānandanātha, the third chapter's colophon to the Śrissarvopanișat, and the final colophon to the Gorakhajogamañjarī. The text could be a composite work consisting of summaries or extracts of different texts. Nonetheless, the Hațhayogamañjari styles itself as a work on Hațhayoga. The terms hațhayoga and hațhavidya are used in each chapter and it contains a description of the hathayogi (p. 32). Its opening verses (2-5) state that it is an explanation of the Hathapradīpikā in a vernacular language (bhāṣā). It certainly covers most of the content of the Hathapradipikā, but also includes additional material on yama, niyama, pratyāhāra, dhyāna, etc. A significant difference is that much of the Hațhapradīikikàs discourse on Rājayoga has been omitted. Like other Brajbhāṣā texts, such as the Jogapradīpyakā (1737 CE), the author of the Hațhayogamañjari equates vajrolimudrā with Rajjayoga. I am yet to consult a manuscript of this work or even find a reference to it in a manuscript catalogue or another yoga text. It may be the work referred to as the Jogamañjari (acc. no. 6543, Rajasthan Pracya Vidya Pratisthan, Bikaner, Rajasthan) by Gharote et al. (2006a, lxvii). However, the librarian at this library in Bikaner was unable to locate this manuscript when James Mallinson and I visited on separate occasions in 2018. The Hațhayogamañjarī mentions devotion to Rāma (e.g., p. 10, v. 33 and p. 18, v. 25 and the last line) and was probably compiled in the same period and milieu as the Jogapradīpyakā. 
Hațapradīpikā with ten chapters (18th c. $)^{20}$

Siddhāntamuktāvalī (18th c.), ${ }^{21}$ etc.

In particular, the last two texts are literally extended versions of the Hathapradipika because their authors simply added more verses to the original work and created additional chapters on related topics. In fact, these "extended texts" enlarge on the Hațapradipikā in two ways. Firstly, they integrate other types of yoga and various related topics. For example, the Hațharatnāvali combines the fourfold system of yoga (i.e., Mantra-, Laya-, Hața- and Rājayoga) of earlier works, such as the Amaraughaprabodha, with the astäninga format. The author of the Hatharatnāvali borrowed over one hundred and thirty verses from the Hațhapradīpikā and mentions Svātmārāma's views on several specific matters (Gharote et al. 2002, xx). The Siddhāntamuktāvalī significantly extends the original Hațhapradīpika by adding sections on the purification of the channels (nāạissuddhi), meditation (dhyāna), cheating death (kälavañcana) and indifference (audāsinnya). A similar array of topics is seen in the Yogamārgaprakāśikā (16-18th c. ${ }^{22}$ ), which adopts the fourfold system of yoga noted above. Its teachings on Hațhayoga follow for the most part the Hațhapradipikā.

Secondly, the repertoire of techniques in most of the texts which follow the Hathapradīpikā became larger. As shown in Table 19.2, the number of āsanas increases most significantly. ${ }^{23}$ However, it is also the case that techniques were added to the standard collections of the șațarmas and mudrās. The original six therapeutic interventions known as the șt țarma form the basis of a repertoire of twenty-one techniques in the Hațayogasam hitā. This work also adds fifteen mudrās to the usual ten that are taught in Hathayoga. Furthermore, these texts provide greater detail on many of the mudrās. For example, the Hațhābhyāsapaddhati contains the most elaborate teachings on vajroli, which is taught in great detail along with its preliminary practices and medical applications. In table 19.2 the number of kumbhakas remains almost the same but, generally speaking, these texts contain many more verses on prānāyāma. ${ }^{24}$

20 On the date of the Hațhapradīpikā with ten chapters, see Birch 2018a, 8 note 32.

21 On the date of the Siddhāntamuktāvalī, see Birch 2018, 127.

22 On the date of the Yogamārgaprakāsikiā, see Birch 2018a, 8 note 29.

23 The Hatharatnāvalī lists eighty-four āsanas but describes only thirty-six of them. Other examples from this period of yoga texts with the names and descriptions of large numbers of āsanas include the Siddhāntamuktāvalī (96 āsanas), the Hațhābhyāsapaddhati (112 āsanas), the Yogāsana (108 āsanas), the Yogāsanamālā (110 āsanas) and the Ujjain manuscript (No. 3537) of the Yogacintämaṇi (54 äsanas described and two lists of over eighty names of äsanas). For further information on this, see Birch 2018.

For example, the Hațharatnāvalī has 97 verses in its chapter on prānāyāma whereas 
TABLE 19.2 The proliferation of post-fifteenth Hațhayogic techniques

Texts

Number of techniques

āsana șațkarma kumbhaka mudrā

\begin{tabular}{lcccc}
\hline Hațhapradīpikā (15th c.) & 15 & 6 & 8 & 10 \\
Hațharatnāvāli (17th c.) & 84 & 8 & 9 & 10 \\
Hațhayogasamhitā (17th c.) & 32 & 21 & 8 & 25 \\
Hațhäbhyāsapaddhati (18th c.) & 112 & 9 & 8 & 10
\end{tabular}

The period in which these extended works arose was one in which physical practices were documented on an unprecedented scale. Monographic works were composed on particular techniques that had become, by this time, closely associated with Hathayoga. Examples include the following:
Kumbhakapaddhati (17th c.) $)^{25}$
Satkarmasangraha (18th c. $)^{26}$
Yogāsanamālä (18th century) ${ }^{27}$
Yogāsana (19th century), ${ }^{28}$ etc.

The composition of such works indicates ongoing innovation and syncretisation in the practice of āsana, prānayyama and the șațkarma that is also reflected in the extended Hathayoga texts mentioned above. The Kumbhakapaddhati describes over seventy varieties of breath retention (kumbhaka) and the Satkarmasangraha borrowed many of its additional therapeutic interventions from

the Hațhapradīpikā has 78 . The Hațhatattvakaumudī has five chapters on prānāyāma (9, 10, 12, 37-38), namely, the preliminary auxiliaries and rules of practice for prānāyāma (prānāyāmapūrvāingasādhanavidhi), an explanation of the names, nature and characteristics of kumbhakas (kumbhakanāmasvarüpaguna), breathing methods for quelling suffering (kleśaghnavāyusādhana), necessary rules for prāṇāyāma (prāṇāyāmakartaryavidhi) and an explanation of prānāyāma (prānāāāmavivecana), which total more than 240 verses. The Siddhāntamuktāvalī (ff. 53-86v), the Yogacintämaṇi (pp. 161-220) and the Yuktabhavadeva (pp. 107-143) have large sections on prānāyāma as well.

25 On the date of the Kumbhakapaddhati, see Birch 2018a, 9 note 41.

26 On the date of the Satkarmasaingraha, see Birch 2018a, 5o.

27 The one available manuscript of the Yogāsanamālā was completed on Wednesday, 20 January 1790 CE (miti mahișa sudī 5 budhavasare saṃvat 1846).

28 See below for information on the date of this text. 
Āyurveda. ${ }^{29}$ All of these works build on the content of the Hathapradipika that was relevant to their respective topics.

\subsection{Extended Works: Scholarly vs Praxis-Orientated}

Some of the extended works are the result of scholarly efforts to synthesise and elaborate on material from earlier works, whereas others appear to document, perhaps for the first time, a practice that was in use at the time of writing. A good example of a more scholarly extended work is the Hatharat$n \bar{a} v a l \bar{\imath}$, which was composed by Śrinnivāsa. At the beginning of the first chapter, he presents himself as a learned writer by informing the reader that he is an eminent astrologer who excels in the Vedas, Vedānta, the works of Patañjali, Vyākaraṇa, Tantra, Sāṅkhya, Nyāya, Vaiśeșika, as well as various other texts and philosophies. ${ }^{30}$ His remarks on the Hathapradipika indicate that he was responding to deficiencies which he perceived in that work. ${ }^{31}$ In particular, his list of eighty-four āsanas appears to have been the creation of a scholar who felt compelled to elaborate on references to this canonical number of postures in early works, such as the Dattātreyayogaśästra and the Vivekamārtanda ${ }^{32}$ In fact, Śrīnivāsa's list of eighty-four names of postures is preceded and followed by verses of the Vivekamärtanda and the Hațapradipikā, which state that Siva taught eighty-four āsanas. ${ }^{33}$ The compilatory nature of his collection is revealed by explicit references to and tacit borrowings from the Hațhapradīpikā, the Yogayājñavalkya, and the Dattātreyayogaśāstra in his descriptions of thirty-six a asanas. ${ }^{34}$ Also, Śrīnivāsa incorporated into the list at least twelve variations of certain basic postures, which further suggests that this list was a scholarly contrivance arising from his intention to expatiate on earlier textual references to eighty-four âsanas. ${ }^{35}$

29 For further details on this, see Birch 2018a, 49-56.

$30 \quad H a t ̦ h a r a t n a \bar{a} v a l \bar{\imath} 1.2$ (vede vedāntaśāstre phanipatiracite śabdaśāstre svaśāstre tantre prābhākarīye kaṇabhugabhihite nyāyaratnārnạavendu h | sān்khye sārasvatīye vividhamatimate tattvacintāmanijñah śrimmajjyotirvid agre saravaratanujo rājate śrīnivāsaḥ ||).

31 For example, see Śrīnivāsa's commentary to Hațharatnāvalī 1.27 and 2.86.

32 For references and translations of the relevant verses, see Birch 2018, 107-108.

33 Hațharatnāvalī 3.7 ( Vivekamārtaṇ̣a 8-10) and 3.23 (= Hațhapradīpikā 1.35).

34 In the Hațharatnāvalì's section on àsana, the Hațhapradīpikā, the Yogayājñavalkya, and the Dattātreyayogaśāstra are cited by name at $3.23,3.35$ and 3.36, respectively. Hațharatnāvalī 3.42-43, 51-54, 57-58, etc., are tacitly borrowed from the Hațapradīpikā. Also, Hațharatñāvalī 3.77 is a rewriting of Vivekamārtanda 92.

35 Six types of mayūrāsana are mentioned in Hațaratnāvalī 3.10 and five are described at 3.42-47; three of matsyendrāsana are mentioned in 3.12 and described at 3.58-6o; two of paścimatānāsana are mentioned in 3.13, and both are described at 3.66-68; and possibly five of kukkuțāsana are mentioned in 3.17 (if one assumes that ākārita and bandhacūlī, 
The scholarly efforts of Śrīnivāsa in compiling a list of āsanas can be contrasted with what one might call "praxis-orientated works" in this category, such as the Hațhäbhyāsapaddhati and the chapter on äsana in the Siddhāntamuktāvalī. These works are composed in the same style as the early Hațhayoga texts; they are prescriptive and focus on praxis rather than theory. Their collections of äsanas do not appear to be a synthesis of earlier textual sources because their authors do not cite or allude to any sources, and a large proportion of their assanas is not attested in earlier texts. In the case of the Hațhabhyāsapaddhati, innovations seem apparent in the use of moving âsanas, sequencing, linking postures, counterposing and the use of props, such as ropes and walls (Birch 2018, 134-135). Therefore, it is likely that innovation played a significant role in the proliferation of techniques seen in these praxisorientated extended works which postdate the Hațapradipikā. Although some of these complex postures may predate the fifteenth century, as revealed by iconography, the codification of large numbers of complex postures in texts specifically on Hațhayoga, as well as works on yoga broadly conceived, such as the Jogapradipyaka, appears to have emerged from the seventeenth century onwards. In fact, only a small portion of the aggregate number of these āsanas are anticipated by the earlier sculptural collections of the Mehudi gate, Brahmanath temple and Hampi, ${ }^{36}$ which further suggests that a certain degree of innovation was probably at play during Hathayoga's floruit.

There is little evidence to indicate that scholarly extended works, such as the Hațaratnāvali, and the compendiums mentioned below were sources of information for Kṛṣnamācārya, Swāmī Śivānanda and other gurus who popularized physical yoga in the early twentieth century. These gurus deferred to the Pātañjalayogaśāstra and the Hațhapradīpikā in their publications. Nonetheless, there is significant evidence that they surreptitiously adopted postures from traditions of a sana practice that were prevalent in certain regions of India in the eighteenth and nineteenth century. The traces of these traditions are discernible through texts such as the Hațhäbhyāsapaddhati, the Jogapradīpyakā and the Yogāsana ${ }^{37}$ which preserve teachings on large distinct collections

which are included among kukkuța, ekapädakakukkuța and pārśvakukkuța, are variations of the same posture).

36 On large collections of äsanas at these locations, see Vijaya Sarde 2015 and 2017, and Seth Powell 2018.

37 The āsanas of the Yogāsana, most of which correspond to untraced Sanskrit descriptions quoted in a commentary on the Yogasūtra by Śrīkṛṣnavallabhācārya (1939), were reproduced in several early twentieth-century publications, one of which was Swāmī Śivānanda's book Yoga Asanas. This will be discussed at length in a forthcoming publication. 
of complex āsanas (Birch, forthcoming). The growing emphasis on complex àsanas and mudrās in practical works such as the Siddhäntamuktāvalī also occurs for the first time in the literature of erudite Brahmins of the same era. I shall now turn my attention to these more scholarly works which integrated Hațha- and Rājayoga into more orthodox conceptions of yoga.

\subsection{Yoga Compendiums}

A century or so after the Hathapradīpikā, a number of lengthy compendiums on yoga were composed. Most of these compendiums do not focus on any particular type of yoga, but treat the subject more generally by combining many sources, including texts on Hațhayoga. Generally speaking, these compendiums are scholarly works of literature, which incorporate philosophy and metaphysics on a more ambitious scale than earlier texts, such as the Hațapradīpika. In a sense, their authors produced a new discourse on yoga by combining the teachings of Hațha- and Rājayoga with those of the Pātañjalayogaśāstra and various Brahmanical texts, including the Bhagavadgìtā, the Mahābhārata, early Upaniṣads, Purānas and Dharmaśāstras. In the earlytwentieth century, a synthesis of the same genres was favoured by Brahmin gurus such as Kṛ̣ṇamācārya, Swāmī Śivānanda and Swāmī Kuvalayānanda, who combined physical yoga techniques with concepts from Pātañjalayoga and Advaitavedānta, as well as metaphysics from tantric traditions, to teach yoga to an international audience. ${ }^{38}$

The compendiums to which I am primarily referring are: ${ }^{39}$

Yogacintāmaṇi of Godāvaramiśra (16th c.)

Yogapañcāsiikā (early 16 th c. $)^{40}$

38 One should consult the work of Elizabeth de Michelis (2004) and Mark Singleton (2010) for the modern elements, such as neo-Vedānta and physical culture, that also shaped the teachings of these gurus. Some significant similarities in their teachings with the sources I am discussing include the use of the aștāinga format, the integration of bandhas and mudrās with āsana and prānāyāma, the importance of inverted āsanas, the identification of samādhi with Advaitavedānta concepts and, above all, the trans-sectarian approach to compiling their teachings.

39 For dating, please refer to Birch 2018a, unless otherwise indicated.

40 The Yogapañcāśika might be the earliest attempt to integrate Hațha- and Rājayoga with Pātañjalayoga. The text is cited by name in a Sanskrit work called the Vivekamukura, which was composed by Nṛsimha Bhāratīya, according to its last verse (97). If this is the same author who wrote the commentary called the Subodhinī on the Vedāntasāra, as stated by Thangaswami (1980, 36o-361), then Nṛsimha Bhāratī of Varanasi was active in the late sixteenth century. Unlike other compilations in this list, the Yogapañcāśikā is a short 
Upāsanāsārasañgraha (16th c. $)^{41}$

Yogacintāmaṇi of Śivānandasarasvatī (17th c.)

Yuktabhavadeva (17th c.)

Tattvabinduyoga of Rāmacandra (17-18th c. $)^{42}$

Hațhasankketacandrikā (18th c.)

Hațhatattvakaumudī (18th c.)

Yogasārasangraha (18th c.) $)^{43}$

Yoga Upanișads (18th c.) $)^{44}$

Räjatarala (late 18th-19th c.) ${ }^{45}$

work of merely fifty verses that cites only the Pātañjalayogaśāstra. It teaches an aștâñ gayoga. The first four auxiliaries are Hațhayoga, and the second four, Rājayoga. It is a Śaiva work that aims at raising kuṇdalinī, uniting Śakti with Śiva and attaining jī̌vanmukti, followed by videhamukti when all prārabdakarma is extinguished. Its yoga is not intended for those who deny the validity of scripture (nāstika), but for male life-long brahmacārins (nrnaișthika). This text is unpublished and, as far as I am aware, preserved by only one manuscript, which has several small lacunae.

41 Bouy 1994, 89-92.

42 Birch 2014, 415, 434 note 71.

43 The Yogasārasangraha undoubtedly postdates the Hațhapradīpikā and the Śivayogapradipika. The latter was probably composed in the late fifteenth century. However, the Yogasārasañgraha may post-date the Hatharatnāvalī (seventeenth century), as it shares a verse on bhujangikarana, a technique that is only taught in the Haṭharatnāvalī (2.31), as far as I am aware (cf. Yogasārasangraha p. 28, lines 4-5). Also, there are other verses on Hațhayoga that seem to follow the Hațharatnāvalī rather than the Hațhapradīpikā (e.g., Yogasārasañgraha p. 55, lines 8-14 Hațharatnāvalī 2.32-35). The Yogasārasañgraha's terminus ad quem would probably be one of its manuscripts. Several appear to be reported in the New Catalogus Catalogorum (hereafter NCC), but I have not had the opportunity to consult any of them.

44 These so-called Yoga Upanișads are part of a recent recension compiled in South India in the first half of the eighteenth century and commented on by Upanișadbrahmayogin (See Bouy 1994). They include the Yogatattvopanișat, the Dhyānabindūpanișat, the Nādabindūpanișat, the Śāndilyopanișat, the Yogacūḍamanyupanișat, the Yogakuṇdalinyupanișat, the Yogaśikhopanișat, the Darśanopanișat, the Maṇdalabrāhmanopanișat, the Saubhägyalakṣmyupanișat and the Varăhopanișat.

45 The Rājatarala is a lengthy commentary on the Yogatārāvalī (circa 14th c.) that was composed by Rāmasvāmipaṇịita, who is described as a worshipper of Śankarācārya's feet (śriśamkarācāryapādakiṃkara). He cites the Maṇdalabrāhmanopaniṣat (ms. no. 72330, f. 29v), which means that the Rajjatarala was composed after the corpus of one hundred and eight Upanișads, that is, the mid-eighteenth century (Bouy 1994, 6, 34, etc.). Also, a verse pays homage to a Dakșināmūrti in the city of Śrīsaila, near Kadalī, which appears to locate the work in Andhra Pradesh (Mahadevan 2018, 68). It is preserved by one undated palm-leaf manuscript (No. 72330) in Telugu script at the Adyar Library and Research Centre, Chennai, and an undated transcript (No. B378) in Devanagari (circa 2oth century) at the Oriental Research Institute, Mysore. 
Yogasandhy $\bar{a}$ (early 19th c.) ${ }^{46}$

Gorakṣasiddhāntasangraha (19th c. $)^{47}$

The authors of these compendiums often combined yoga teachings from different traditions seamlessly. For example, in the Yogacintāmaṇi, Godāvaramiśra integrated the physical methods of Hathayoga with the auxiliaries of $\bar{a} s a n a$ and prānāayāma in Patañjali's așțānga system (see below). Similarly, in Śivānanda's Yogacintāmaṇi and Bhavadeva's Yuktabhavadeva, the meditative state of Rājayoga became the equivalent of Patañjali's highest stage of samādhi, called asamprajñätasamādhi. ${ }^{48}$ Most authors of these works were inclined towards Vedānta. They cited the teachings of the Upanișads to express the gnostic insights that arise from samädhi. Also, they incorporated theistic teachings on yoga from the Purānas and Tantras, and were comfortable with defining yoga as meditation (i.e., cittavrttinirodha), on the one hand, and then as the union of the self with a deity, on the other hand. Likewise, their descriptions of dhäraña and dhyanna juxtapose Patañjali's definition of "binding the mind to one place, etc.," with tantric visualizations of the five elements and deities.

\subsection{Godāvaramiśra's and Śivānanda's Thought Gems on Yoga}

In the Yogacintāmaṇi, Godāvaramiśra's method of synthesising Hațhayoga with other yogas is typical of this genre. ${ }^{49}$ Godāvaramiśra was a chief minister (mantrivara) and preceptor (räjaguru) to the Orissan king Pratāparudradeva,

46 According to the final colophon, the Yogasandhyā was composed by Śrīsadāśivanārāyaṇabrahmacāri, whose guru was Śrīmajjagannāthacaitanyabrahmacāri. They belonged to the tradition of the Śrngerimațha. The final verse mentions the date of composition in the bhütasañkhya system. If the term dharma represents the number eight, it would have been completed in VS 1861 (= 1804CE), when the sun was in the ninth nakșatra (tapas) and the moon full. See Yogasandhyā, p. 203 (rākeśarasadharmorvvisammite vaikrame 'bdake | tapasine ca rākāyām satkrtị pürṇatāmitāa). I would like to thank for their comments on this verse Somadeva Vasudeva, Péter Szántó, James Mallinson and, in particular, Chris Minkowski, who suggested that dharma could mean 4,6 or 8 .

47 The date of the Gorakșasiddhāntasangraha is not certain, although it post-dates the Siddhasiddhāntapaddhati, which might be as late as the eighteenth century (Mallinson 2014, 170-171).

48 Śivānanda's Yogacintāmaṇi, p. 9 (na tatra kiñ cidvedyaṃ samprajñāyata ity asaṃprajñātaḥ samādhị | ayam nirbüja iti nirvikalpa iti nirālamba iti räjayoga-iti cocyate) and Yuktabhavadeva 1.33 ([...] sa eva nirvikalpaḥ samādhih sadā savikalpakajñānābhāvāt || sa eva ca rājayogah).

49 This work survives in a single, incomplete manuscript, which is dated Wednesday, 16th November ${ }_{1715}$ CE. Yogacintāmaṇi (f. 132v, lines 7-8): saṃvat $177^{2}$ varșe kārttika vadi māvāsyā budhavāsare likhitam. 
who ruled in the early sixteenth century. In addition to yoga, Godāvaramiśra wrote works on various topics, including Advaitavedānta (the Advaitadarpana ${ }^{50}$ ), Tantra (the Tantracintāmani $i$ ) and an extensive treatise on politics and warfare (the Hariharacaturanga). ${ }^{51}$ His view of yoga was mainly shaped by the Pātañjalayogaśāstra. He acknowledges this at the beginning of his work:

In this text, I summarise and examine Patañjali's doctrine, which was explained by Vyāsa, Vācaspati and Bhojadeva and which is validated and [yet] overlooked elsewhere. ${ }^{52}$

Although Godāvaramiśra discusses only some of the sūtras of the Pātañjalayogaśāstra in an order that fits the design of his work, he begins with the first one (atha yogānuśāsanam) and, in his discussion of it, cites with attribution passages from the Gārudapurāna (sic), the Bhagavadgittā, the Brahmāṇdapurāna and the Kürmapurāna, as well as the sages Yājñavalkya (i.e., the Yäjñavalkyasm$r t i)$ and Maharșimatanga. ${ }^{53}$ The first half of the Yogacintämani is concerned with general topics, such as definitions of yoga, the types of samādhi and so on. The latter half is structured on the eight auxiliaries (aștānga) of Pātañjalayoga, and it is in his discussions of āsana, diet and prānāyāma that he cites

50 The Yogacintāmaṇi (f. 13ıv lines 7-8) of Godāvaramiśra states that he wrote the dvaitadarpana: "Now, they have been explained together by me in the Dvaitadarpana" ([...] asmābhir atha dvaitadarpaṇe yugapadanuvarnitāạ [...]). However, it seems that atha dvaitadarpaṇe is a scribal error for athädvaitadarpaṇe, because yugapadanuvarnitāh refers back to two works: the Sanksșepaśärïrakavārttika, which was composed by his paternal grandfather (pitämahacarana) and the Advaitacintāmaṇi by his father (pitrcarana). The NCC (vol. 6, 126) reports that Godāvaramiśra wrote the Advaitadarpaṇa because it is quoted in his Hariharacaturanga (p. 178, v. 22; p. 196, v. 502). This is affirmed in a summary of the Hariharacaturanga (Meulenbeld 2000, 562-563).

51 For more information on Godāvaramiśra's family and works, see the NCC vol. 6, 1971, 126 and Meulenbeld 200o, 562-563.

52 Yogacintāmaṇi, f. 1v, lines 4-5 (yad vyāsavācaspatibhojadevaih pātañjalīyam niraṇāyi tattvam | anyatra siddham yad upekșitam ca tad atra sañkșipya nirūpayāmi $|3| \mid)$ The codex reads upekșitam, but Gode $(1953,474)$ transcribes it as apekșitam. Whether he was tacitly emending upekșitam to apekșitam is not clear. He may have emended because the meaning of apekșita is more consistent with siddha, but it seems possible that upekșita was intended to contrast with siddha, as I have translated.

53 One would expect that the Matangapārameśvaratantra is meant by this attribution. However, I have not found the cited verse in the published edition of this tantra. The verse in the Yogacintāmani (f. 3v, lines $5^{-7}$ ) is agniștomādikān yajñān vihāya dvijasattama hyogābhyāsaratah śāntah paraṃ brahmādhigacchati || brāhmanakșatriyaviśām strīsuudrāṇām ca pāvanam śântaye karmaṇām anyad yogān nāsti vimuktaye $\|$. This verse is found in the Viṣnudharma (98.016). 
two works on Hațhayoga: the Hațhapradīpikā (hațhayoge-f. 39v, l. 8) and the Dattātreyayogaśāstra (dattātreyah-f. 36 r, line 1; f. 40v, line 3). He also cites the Yogayäjñavalkya (yäjñavalkyah-f. $36 \mathrm{r}$, line 6; f. 36v, line 6; f. 37v, line 7; f. $38 \mathrm{v}$, line 7 ), which was a source text for the Hathapradipikā. The other sources on these topics are the Dharmaputrikā, the Pavanayogasangraha, the Ägneyapurāna and the Matangapārameśvaratantra. Therefore, on the topic of āsana, Godāvaramiśra created a seamless synthesis of hathayogic teachings with those of tantric and brahmanical sources.

Godāvaramiśra's work became the basis of an ambitious attempt by Śivānandasarasvatī to integrate a more extensive and diverse array of Hațhayoga texts with Pātañjalayoga and Brahmanical works. Śivānanda also named his compilation the Yogacintämani. He probably lived in the early-seventeenth century in Varanasi. ${ }^{54} \mathrm{At}$ the end of this text, Sivānanda informs the reader of the material he has included and excluded. He says:

Meditation along with the practices [ancillary to it] have been explained briefly by me according to scripture and my understanding. Listening to and contemplating [the teachings] which are seen in detail and at length only in the Upanișads, have not been discussed for fear of prolixity. I have revealed here all that which is secret in Hațha- and Rājayoga for the delight of yogins. However, that Hathayoga which was practised by Uddālaka, Bhuśuṇḍa and others has not been mentioned by me, because it cannot be accomplished by contemporary [practitioners. Also], the procedures and so forth promoted by the kāpālikas have not been mentioned [because] they contravene the Vedas, Dharmaśāstras and Purānas. ${ }^{55}$

54 The terminus a quo of Śivānanda's Yogacintāmaṇi is Godāvaramiśra's Yogacintāmaṇi (see above). The terminus ad quem is $1630 \mathrm{CE}$, based on two dated manuscripts of the Yogacintāmañi. The first is reported in the catalogue of yoga manuscripts by Kaivalyadhama (2005, 226-227), which gives the author (Śivānandasarasvatī), the library (the Asiatic Society in Mumbai), the manuscript number $(1083)$ and the date (vs $1687=1630 \mathrm{CE})$. The second manuscript is held at the Panjab University Library and has been catalogued by the Woolner Project (Ms. no. 6922). After this manuscript's final colophon, a scribal comment indicates that it was copied by Rāma on the 13th of the month, Kārttika, in Śāka $155^{2}$ (i.e., Sunday, 17 November 1630 CE). The possibility that Śivānanda was a resident of Varanasi is supported by a reference to his devotion to Viśveśvara, a standard claim of Śaivas who resided there. I would like to thank Alexis Sanderson for pointing this out to me, and he also noted that similar references to Viśveśvara in works of Śaivas who resided in Varanasi can be found in Jñānaśiva's Jñānaratnāvalī and Viśvanātha's Siddhāntaśekhara, which are both Saiddhāntika Paddhatis (personal communication, 24 April 2013).

55 The Yogacintämani pp. 281-282 (with verse numbers added for the clarity of the critical apparatus): nididhyāsanam etat tu mayā sādhanasamyutam | yathāśāstram yathābodham 
Both Godāvaramiśra and Śivānanda excluded the Haṭha techniques of vajrolī, amarolì and sahajolì, presumably because these are the kāpälika practices which would be unacceptable to his brahmanical audience. ${ }^{56}$ The main difference between Godāvaramiśra's and Śivananda's compilations is that the former focused on Pātañjalayoga and cited Hațhayoga texts sparingly, whereas the latter discussed Hațhayoga as forthrightly and comprehensively as the yogas of other traditions, and cited its texts profusely. This is also the case for similar compilations of the time, such as Bhavadevamiśra's Yuktabhavadeva and Sundaradeva's Hațhasankketacandrikā.

\section{$2.5 \quad$ The Polymathy of Bhavadevamiśra}

The synthesis of various philosophies and genres of literature in the yoga compendiums under consideration was created by well-educated Brahmins who were knowledgeable in a wide range of scholarly subjects. A good example of this is the seventeenth-century Bhavadevamiśra, whose Yuktabhavadeva is a digest (nibandha) that integrated teachings of Hațha- and Rajjayoga with those of the Pātañjalayogaśāstra and various Upaniṣads, Purānas, Tantras, Dharmaśāstras and the Epics. Apart from the fact that Bhavadeva cited a wide range of Sanskrit works, the breadth of his learning is attested by the commentaries attributed to him on various śāstras. Manuscript colophons state that he was a Brahmin from Mithila and that his father was Kṛ̣nadevamiśra, his elder brother Baladevamiśra and his teacher Bhavadeva Thakkura. Based on this information, the Bhavadeva who wrote the Yuktabhavadeva also wrote commentaries on the Pātañjalayogaśāstra, ${ }^{57}$ the Brahmasūtra, ${ }^{58}$ the Kāryapra-

sañkșepeṇa nirūpitam ||1|| śravaṇaṃ mananam caiva saviśeșaṃ savistaram | vedānteṣv eva draștaryam noktạ̣ vistarabhītitạ ||2||| rahasyam rājayogasya hațhayogasya yat sthitam | prakāsitam mayā sarvaṃ prītaye yoginām iha $\|_{3}||$ arvācīnair asādhyatvāl likhito na mayā hi sạ̣ | uddālakabhuśuṇ̣̂ādyair hațhayogas tu yaḥ kṛtạ̣ ||4|| kāpālikapraṇitās tu itikartavyatādayaḥ | likhitā na mayā te tu śrutismritivirodhinaḥ ||5||

2b saviśeșaṃ savistaram ] 6922, Ed.; savistaraviśeșakam 3537. 4a arvācīnair ] 3537, 6922; sadhrīcīnair Ed. 4b asādhyatvāl ] 3537; asādhyatvāt Ed.; asādhyatvān 6922. 4b likhito na mayā hi saḥ ] Ed.; likhitvo na mayā hi saḥ 3537; na likhito hi mayā tu saḥ 6922 (hypermetrical). 5 d virodhinah ] 3537, 6922; virodhanāh Ed.

56 The Hațhapradīpika (3.96d) contains a verse that points to the Kāpālika origins of amarolì (... kāpālike khandamate 'marolī ). Amarolì and sahajolì are generally considered to be variations of vajrolī (e.g., Dattātreyogayogaśāstra 31 and 158, Hațhapradīpikā 3.92, etc.).

This commentary is called the Pātañjalīyābhinavabhāsya and several manuscripts of it are held in the Kathmandu National Archives. The chapter colophons of E 1819-9 and A 554522 affirm that Bhavadeva was the son of Kụṣnadeva and the favourite student (priyaśișya) of Țhakkuraśrībhavadeva.

$5^{8}$ This commentary is called the Candrika and the NCC (vol. 15,12$)$ reports that it is by 
$k \bar{a} s a^{59}$ and the Vājasaneyisaṃhitā ${ }^{60}$ as well as a work on Dharmaśāstra called the Dānadharmaprakriy $\bar{a}^{61}$ and another on what appears to be Vaiśeșika philosophy, the Vaiśeșikaratnamālă. ${ }^{62}$ Some manuscript catalogues also attribute to a "Bhavadeva" a commentary called the Abhinavabhāṣya on the Śạndilyasūtra, also known as the Bhaktimìmāmsāsūtra, ${ }^{63}$ and some other works, ${ }^{64}$ but the catalogues I have consulted do not provide enough biographic information to prove that this was the same Bhavadeva who composed the Yuktabhavadeva. Nonetheless, it is clear that Bhavadeva was a scholar whose knowledge extended far beyond the theory and practice of yoga traditions.

Bhavadeva, who was the son of Sanmiśrasrīkṛṣnadeva and the disciple of Țhakkurabhavadeva.

59 This commentary is called the Lïla. The NCC (vol. 4, 98) reports that it is by Bhavadeva, son of Kṛșnadeva of Mithila and pupil of Bhavadeva Ṭhakkura.

6o This commentary is called the Vyākhyānaratnamālä. The NCC $(\operatorname{vol.} .28,60)$ reports that it is by Bhavadeva of Mithila, son of Kṛ̣nadeva and disciple of Bhavadeva Țhakkura.

61 Dānadharmaprakriya was composed by Bhavadevabhațta, son of Kụṣnadevamiśra (NCC vol. 9, 6) at the request of Rudradāsaśreșțhin in 1636-1637 CE (NCC, vol. 16, 172). Kane (1930 vol. 1, 560) points out that this work was by Bhavadeva, son of Kṛṣnadeva of Mithila. In a latter volume (1962, vol. 5, part ii, 28), he attributes the Prāyaścittaprakarana to Bhavadevabhațta.

62 The NCC (vol. 32, 64) reports that the Vaiśeșikaratnamālā was written by Bhavadeva Pandita, son of Kṛ̣nadevamiśra and disciple of Bhavadeva Țhakkura. This appears to be based on a sole manuscript at the Bhandarkar Oriental Research Institute (123 of 1881-1882).

63 In its entry on the commentary called the Abhinavabhāsya on the Śandilyasūtra or Bhaktimìmāmsāsūtra (also called the Śatasūtī or Bhaktisūtra), the NCC $($ vol. 15, 152) reports that this work is found in the manuscript libraries of the Oriental Institute in Baroda, the Prajñā Pāțhaśālā Maṇḍala at Wai and the Sampūrṇānanda library in Varanasi. The catalogues of the first two do not give any biographic information for Bhavadeva and I have not been able to consult catalogues of the Sampūrṇānanda library (SB New DC XII 44408, 44416. ii. 107900. 107911).

64 Other works attributed to a Bhavadeva in the NCC (vol. 16, 172) include the Yogasangraha, the Vyāptivāda and commentaries on the Yogadarpana, the Yogabindu, the Raghuvamiśa (called the Subodhinī) and the Șadaingarudra. Karl Potter's Encyclopedia of Indian Philosophies Bibliography (1983, vol. 1, 475) adds commentaries by a Bhavadeva (dated to 1650) on Bhavānanda's Kārakacakra, Íśvarakṛṣna's Sāñkhyakārikā and the Pañcalakșana section of Gangeśa's Tattvacintāmaṇi, as well as a work on Nyāya called the Anumānaprakaranavyākhyā. 


\section{The Regional Extent of Hațhayoga's Literature on the Eve of Colonialism}

The compendiums of Godāvaramiśra, Śivānanda, Bhavadevamiśra and Sundaradeva endorsed the teachings of Hathayoga ${ }^{65}$ These works were part of a concerted effort among some erudite Brahmins to make Haṭhayoga's physical practices an integral part of the Brahmanical view of yoga, much like the so-called "Yoga Upanișads" that were compiled in South India in the first half of the eighteenth century. Christian Bouy's work (1994) on these Upanișads informs us that the compiler liberally borrowed material from earlier Hațha- and Rājayoga texts, often presenting the physical practice as a way of purifying the mind that would then lead to the realization of vedantic truths. As Bouy $(1994,72)$ notes, the prominence of Hathayoga teachings in these Upanisads indicates that this type of yoga had come into vogue in vedāntic milieus. He says that the interest of vedāntists in Hațhayoga may have started in the fifteenth and sixteenth centuries, and then flourished in the seventeenth and eighteenth centuries.

In addition to the Yoga Upanișads and the Upāsanāsārasangraha, which were examined by Bouy, the Yogasandhyā and the Rājatarala are large exegetical works composed in South India that weave together Pātañjalayoga and Hațhayoga within a vedāntic framework. The other compendiums discussed in this article support Bouy's observations and extend his hypothesis to the region of Northeast India. Godāvaramiśra lived in what is now Orissa, Bhavadeva in Mithila and both Śivānanda and Sundaradeva in Varanasi. The vedāntic overtones in the works of these authors include references to the Upanișads and an emphasis on achieving the liberating gnosis of Brahman. Also, various prosopographic details associate them with Advaitavedānta. Godāvaramiśra's father Balabhadra wrote a text called the Advaitacintāmani and he himself the Advaitadarpaṇa, ${ }^{66}$ Śivānanda mentions Ādiśañkara in his lineage ${ }^{67}$ and, according to manuscript catalogues, Bhavadeva wrote a commentary on the Brahmasütra. Unlike the Yoga Upaniṣads, their works explicitly cite Hațhayoga texts.

65 For information on Sundaradeva and his works, see Birch 2018a, 58-61.

66 Yogacintāmañi (ms. no. 220 of 1882-1883) f. 131v.

67 Yogacintāmaṇi p. 2: "Having bowed to Śrīvyāsa, the ascetic Śankkara, the teacher of the world, [my] teacher Śrīrāmacandra, whose lotus feet are intense bliss, and all of the gods of yogins, the ascetic Śivānanda has written clearly the great Yogacintāmaṇi, which had fallen into an ocean of various texts and has the power to explain everything" (śríryāsam yatiśañkaram bhavagurum śrīrāmacandrạ̣ gurum sāndrānandapadāmbujañ ca nikhilān natvā hi yogīśvarān | nānāgranthapayodhimadhyapatitam śrīyogacintāmaṇim nị̂śeșārthasamarthakaṃ yatiśivānandaḥ karoti sphuțam ||). 
In contrast to this, I am yet to locate any such compendium in Northwest India. However, some of the extended works on Hathayoga can be traced to this region, such as the Siddhāntamuktāvalī, the Hațapradīpikā with ten chapters and the Hathayogamañjarī. These works, along with the Hathābhyāsapaddhati in Maharashtra and Karnataka, are less scholarly and more likely influenced by practitioners of the time in which they were composed.

\section{4}

\section{Conclusion}

The flourishing of literature on Hațhayoga in both North and South India from the sixteenth to eighteenth centuries was concomitant with a growing pervasiveness of references, over the same period, to Hathayoga in Sanskrit literature of various religions and philosophies. ${ }^{68}$ The findings of this paper suggest that Hațhayoga became more prevalent in literature composed during this period and that the Hațapradīpika was instrumental in defining the techniques and structure of practice for this type of yoga. Moreover, distinct physical techniques that became closely associated with Hathayoga, such as non-seated àsanas and mudrās, had become integral to broader conceptions of yoga on the eve of colonialism.

In the period following the Hațhapradipika, it is possible to discern that the praxis and theory of Hațayoga developed in different ways as it became more widely disseminated. In scholarly circles of Northeast India, its codification took on some of the characteristics of the philosophical yogas, as it

68 Beyond the texts I have mentioned above, the following literature of the sixteenth to eighteenth centuries also integrated hathayogic teachings. I mention here only a few examples without detailed references, which will appear in a forthcoming publication. Examples include the Puraścaraṇacandrikā (late-fifteenth century) and the Puraścaraṇārnava (eighteenth century), two Śaiva ritual compilations that incorporated verses on āsanas, some of which occur only in the Hațhapradīpikā; the Merutantra, a relatively recent Śaiva work, which mentions Hațhayoga in relation to prāṇāyāma; Rāmatoṣaṇa Bhațțācārya's Prānatoșin̄i (1820 CE), which has numerous references to Haṭhayoga; Narāyānatīrtha's Yogasiddhāntacandrikā, a commentary on the Pātañjala Yogasūtra, which integrates fifteen yogas with Patañjali's aștānga format and defines Hațhayoga as the auxiliaries of āsana and prāñāyama; Vijñānabhikṣu's Sānkkhyasāra, a philosophical treatise that mentions both Hațha- and Rājayoga; Narahari's Bodhasāra, a philosophical compendium that has sections on Mantra-, Laya-, Hațha- and Rājayoga; the Bhāvanāpuruṣottama, a Sanskrit drama in which a Kāpālika mentions hațhavidyā as a ladder ascending to Rājayoga (in terms similar to those of the Hațhapradīpikā); and the Vāsișthamahārāmāyanatātparyaprakāśa, a commentary on the Yogavāsișța, which mentions both Hațha- and Rājayoga, etc. 
was integrated with the Pātañjalayogaśāstra and Brahmanical sources. This development resulted in a more syncretic and sophisticated discourse around the physical techniques. The social background of the authors of these compendiums was diverse. Some were sannyāsins, such as Śivānandasarasvatī and Śrīsadāśivanārāyaṇabrahmacāri, whereas others identified themselves according to their professions, which included medicine, politics and astronomy (i.e., Sundaradeva, Godāvaramiśra and Śrīnivāsa, respectively).

In contrast to the scholarly compendiums of the northeast, the extended works on Hathayoga that arose in the northwest of India retained the more praxis-orientated focus of the Hathapradipika , which they enlarged upon by adding more techniques and other auxiliaries, such as yama and niyama. Although not much is known of the authors of these works, renunciant traditions in this region seemed reasonably active in producing manuals on yoga, such as the Hațhayogamañjari and the Jogapradīpyakā, and monographic works, such as the Yogāsanamāla and the Yogāsana, whose content is related to the Hațhapradipika and its extended texts.

From the Amaraughaprabodha to the current day, Hațhayoga has been distinguished by physical methods of practice. In the early period the practice centred on breath retentions with physical locks $(m u d r \bar{a})$, and it burgeoned over the centuries to include an array of complex postures, șațarma and mudrās. Although these physical techniques were never particular to Hațhayoga, the textual evidence suggests that after the sixteenth century Hathayoga became a dominant paradigm for the practice of physical yoga across most of the Indian subcontinent, and this paradigm was significantly shaped by the content of the Hațhapradipikā. As outlined in this article, the floruit of Hațhayoga was a period in which its techniques proliferated, particularly in praxis-orientated manuals, and its literature diversified as authors of various backgrounds, most notably erudite Brahmins, attempted to expand and integrate it with other yogas and different religions. By the eighteenth century, this extensive literary activity appears to have peaked, but the momentum behind it carried the notion of Hathayoga into the royal courts of Mysore and Jodhpur in the nineteenth century, ${ }^{69}$ and placed it firmly at the centre of the revival of postural practice in the twentieth century. ${ }^{70}$

69 In the mid-nineteenth century, the Mahārāja of Mysore, Mummaḍi Kṛṣnarāja Woḍeyar III, commissioned a royal compendium called the Śrtattvanidhi, which had a chapter on āsanas that was based on the Hațāahyāsapaddhati (Birch 2018, 131-132). In the early nineteenth century, the Mahārāja of Marwar had built two temples in Jodhpur (the Mahāmandir and the Udai Mandir) with murals of eighty-four Siddhas in complex āsanas, many of which correspond to those in the Jogapradipyakä (Bühnemann 2007, 102). 


\section{Acknowledgements}

I would like to thank Jacqueline Hargreaves for her comments on numerous drafts, and also Gudrun Bühnemann, Elizabeth de Michelis, Dominic Goodall, Shaman Hatley and Mark Singleton, who commented on earlier drafts. I'm particularly grateful to James Mallinson for his detailed comments and for sharing unpublished research. My research for this paper was funded by the European Research Council (ERC) under the European Union's Horizon 2020 research and innovation programme (grant agreement No 647963).

\section{Abbreviations}

NCC New Catalogus Catalogorum: An Alphabetical Register of Sanskrit and Allied Works and Authors. All Volumes. Madras: University of Madras, 1968 onwards.

\section{References}

\section{Primary Sources}

Aparokșānubhūti. Kamla Devi, ed. Aparokșānubhūtih̨—Vidyāranyakrtayā Aparokșadīpikākhyațīkayā Saṃvalitā. Allahabad: Akshayavața Prakāśana, 1988.

Amanaska. See Birch 2013.

Amaraughaprabodha. See Mallik 1954.

Amrtasiddhi. Unpublished working edition by James Mallinson and Péter-Dániel Szántó for the Haṭha Yoga Project, 2019.

Ānandakanda. S.V. Radhakrsnasastri, ed. Ānandakanda. Tañjapura: Tañjapura Sarasvatimahalgranthalayanirvahaka-samiti, 1952.

Kālacakratantra. Viśvanātha Devaśarma, ed. Kālacakratantrarāja. Calcutta: Asiatic Society, 1985 .

Kumbhakapaddhati. M.L. Gharote and P. Devnath, eds. Kumbhaka Paddhati of Raghuvira: Science of Prānāyāma. Lonavla: Lonavla Yoga Institute, 2000.

Garudapurāna. Part 1. Bombay: Venkatesvara Steam Press (or reprint thereof), 1907. E-

gurus who led the revival of physical yoga in the early twentieth century. For example, Kṛṣnamācārya was inspired by the Hațhābhyāsapaddhati (Birch and Singleton 2019, 4964) and Swāmī Śivānanda of Rishikesh borrowed the majority of the āsanas in his book Yoga Asanas (1934) from earlier sources, one of which dates to the mid-nineteenth century (Birch forthcoming). 
text, Göttingen Register of Electronic Texts in Indian Languages. http://gretil.sub.uni -goettingen.de/gretil/1_sanskr/3_purana/garup1_u.htm. Accessed 1 January 2020.

Guhyasamājatantra. Yukei Matsunaga, ed. Guhyasamājatantra. Osaka: Toho Shuppan Inc., 1978.

Gorakșaśataka. Ms. No. R 7874 (IFP transcript T1095). A transcript of Ms. No. 2831(p), Government Oriental Manuscript Library, Madras (Chennai).

Gheraṇ̣asaṃhitā. See Mallinson 2004.

Jogapradīpikā. M.L. Gharote, ed. Jogapradīpikā. Jodhpur: Rajasthan Oriental Research Institute, 1999.

Jogapradīpyakā. S. Maheśānanda, B.R. Śarmā, G.S. Sahāya and R.K. Bodhe, eds. Jogapradīpyakā of Jayatarāma. Lonavla: Kaivalyadhama Śrīmanmādhava Yogamandira Samiti, 2006.

Jyotsnā. S. Maheśānanda, B.R. Śarmā, G.S. Sahāya and R.K. Bodhe, eds. Brahmānandakṛtā Hațhapradīpikā Jyotsnā. Lonavla: Kaivalyadham Śrīmanmādhav Yogamandir Samiti, 2002.

Tattvabinduyoga. Ms. No. 664 (1883-1884), Bhandarkar Oriental Research Institute, Pune.

Dattātrayayogaśāstra. Unpublished edition by James Mallinson (with the help of Alexis Sanderson, Jason Birch and Péter Szántó) for the Haṭha Yoga Project, 2019.

Dharmaputrikā. Yogī Naraharinātha, ed. Śivadharma Paśupatimatam Śivadharmamahāśāstram Paśupatināthadarśanam. Kathmandu, 1998.

Pātañjalayogaśāstra. Kāśinātha Śāstrī Āgāśe, ed. Vācaspatimiśraviracitațīkā-samvvalitavyāsabhāșyasametāni pātañjalayogasūtrāṇi, tathā bhojadevaviracitarājamārtaṇ̂ābhidhavrttisametāni pātañjalayogasūtrāṇi. sūtrapāṭasūtravarṇānukramasūcībhyām ca sanāthīkrtāni. Ānandāśrama Sanskrit Series, no. 47. Pune: Ānandāśramamudraṇālaye, 1904.

Puraścaranacandrikā. NGMPP A42/5, National Archives of Kathmandu, Nepal.

Puraścaraṇārṇava. Pratāpasiṃha Sāhadeva and Muralīdhara Jhā, eds. Puraścaryārnava: a Treatise Dealing with Theory and Practice of Tantric Worship. Delhi: Chaukhamba Sanskrit Pratishthan, 1985.

Prāṇatoṣiṇi. Rāmatoṣaṇa Bhaț̣a and Saumyānanda Nātha, eds. Prāṇatoṣiṇittantra. Calcutta: Nababhārata Pābaliśārsa, 1991.

Bodhasāra. J. Cover, G. Cover, and K.V. Mande, eds. Bodhasāra: an Eighteenth Century Sanskrit Treasure by Narahari. Charleston, S.C.: CreateSpace, 2010.

Bhāvanāpuruṣottama of Ratnakhețaśrīnivāsadīkṣita. Siromani S. Swaminatha Sastri, ed. Bhāvanāpuruṣottamam. Tañjāvūr: Sarasvatīmahālaya Nirvāhakasamiti, 1979.

Maṇdalabrāhmaṇopanișat. Pandit A. Mahadeva Sastri, ed. Yoga Upanișads with the Commentary of ŚrīUpanișadbrahmayogin. Madras: The Adyar Library and Research Centre, 1968.

Matañgapārameśvaratantra. N.R. Bhatt, ed. Matañgapāramśvarāgama, avec le com- 
mentaire de Bhațta Rāmakaṇtha. 2 volumes. Pondicherry: Institut Français d'Indologie, 1977-1982.

Merutantra. Paṇdita Raghunāthaśāstri, ed. Merutantra. Bombay: Srivenkatesvara Steam Press, 19o8. E-text of the Muktabodha Digital Library. http://muktabodha.org. Yājñavalkyasmṛti. The Śāstris at the Santurāmātmajasundaramalakheḍa, eds. Maharșivaryaśrīyogiyājñavalkyaśisyaviracitā Yājñavalkyasmṛtị Vijñāneśvara viracitamitākșarāryākhyāsamalan்krtā. Mumbai: Śrīveñkațeśvara Mudraṇayantrālaya, 1919.

Yuktabhavadeva. See Gharote et al. 2002.

Yoga Upanișads. Pandit A. Mahadeva Sastri, ed. Yoga Upanișads with the Commentary of Śrï Upanișadbrahmayogin. Madras: The Adyar Library and Research Centre, 1968.

Yogacintāmaṇi of Godāvaramiśra. Ms. No. 220 (1882-1883), Bhandarkar Oriental Research Institute, Pune.

Yogacintāmaṇi of Śivānandasarasvatī. Haridās Śarma, ed. Calcutta: Calcutta Oriental Press, n.d.

Yogacintāmaṇi of Śivānandasarasvatī. Ms. No. 3537, Scindia Oriental Research Institute, Ujjain, India.

Yogacintāmaṇi of Śivānandasarasvatī. Ms. No. 6922, Panjab University Library, Lahore, Pakistan.

Yogatārāvalī. Swāmī Śrīdayānanda Śāstrī, ed. Śrīmacchañkarābhagavatpādaviracitā Yogatārāvalī. Varanasi: Vārāṇaseya Saṃskṛta Saṃsthāna, 1982.

Yogapañcāśikā. Ms. No. 29917 (begins at f. 7v), Sarasvati Bhavan Library, Sampurnanand Sanskrit University, Varanasi.

Yogabïja. Rāmalāla Śrīvāstava, ed. Yogabïja of Gorakhanātha. Gorakhapur: Gorakhanāth Mandir, 1982.

Yogamārgaprakāśikā. Giradhara Śāstri, ed. Śrīmahāntayugaladāsanirmita-yogamārgaprakāśikā. Bombay: Śrīvenkațeśvara Steam Press, 1904.

Yogayājñavalkya. Sri Prahlad Divanji, ed. Yogayājñavalkya: A Treatise on Yoga as Taught by Yogī Yãjñavalkya. B.B.R.A. Society's Monograph, no. 3. Bombay: 1954.

Yogasandhyā. Gañgāviṣṇu Śrīkṛṣnadāsa, ed. Yogasandhyā bhāṣāțīkāsahitā |(sādhana karanevāloṃko amrtakī latā) vedaśāstrasampanna dharmamūrti śrīyuta jagannātha caitanya brahmacārī̄īke caraṇāravindānurāgī așțāñga yogamem kuśala śrīsadāśiva nārāyaṇa brahmacārī nirmita. Mumbai: Lakṣmīvenkațeśvara Steam Press, 1954.

Yogasārasañgraha. IFP transcript T859 (based on D4373). E-text of the Muktabodha Digital Library. http://muktabodha.org.

Yogasiddhāntacandrikā. Pạ̣dita Ratna Gopāla Bhatta, ed. Yogadarśanam with a Commentary Called the Yogasiddhāntacandrikā of Nārāyaṇatīrtha. Benares: Vidyā Vilāsa Press, 1910.

Yogāsana (jaina). A photocopy $(\mathrm{R} 635 \mathrm{Y} 8,15294)$ held at the library of the Kaivalyadhama Yoga Institute. A stamp on a folio indicates the Rajasthān Prācya Vidyā Pratișṭhān, Bīkāner. 
Yogāsanamālā. A photocopy (R635Y8) at the library of the Kaivalyadhama Yoga Institute, Lonavla.

Rājatarala. Ms. No. 72330, Adyar Library and Research Centre, Chennai.

Rājayogāmrtasāra. Ms. No. 22/211, Bhārat Itihās Samśodak Maṇụal, Pune.

Vasișthasaṃhitā. Philosophico-Literary Research Department, ed. Vasiștha Saṃhitā

(Yogakāṇda). Revised edition. Lonavla: The Kaivalyadhama S.M.Y.M. Samiti, 2005.

Vivekamārtanda. Ms. No.411o at the Central Library, Baroda.

Vivekamukura. Padma Padmanabhan, ed. "Vivekamukura of Nṛsiṃha Bhāratī (Edited with Introduction, Notes and Index)," The Adyar Library Bulletin 78-79 (2014-2015): $617-665$.

Śāradātilakatantra. Arthur Avalon, ed. Śārada-Tilaka-Tantra. Delhi: Motilal Banarsidass, 1996.

Śivasaṃhitā. James Mallinson, ed. The Śiva Saṃhitā: A Critical Edition and an English Translation. Woodstock: YogaVidya.com, 2007

Śivasvarodaya. Swami Maheshananda, et al., eds. Śivasvarodayah: A Critical EditionEnglish Version. Lonavla: Kaivalyadhama S.M.Y.M. Samiti, 2015.

Śritattvanidhi. The folios on àsana of a manuscript of this work at the Mysore Palace were photographed and published in Sjoman 1996.

Sacitra Vyāvahārika Yoga athavā Samādhi-Mārga. Pāṇụuranga Gopālabāla Mahājana, ed. Sacitra Vyāvahārika Yoga athavā Samādhi-Mārga. Pune, Mumbai: Pustake Milaṇyāce Ṭhikāṇa (undated).

Satkarmasangraha. See Harshe 1970.

Sāṅkhyasāra. Badarī Nārāyaṇa Pañcolī, ed. Sāṅkhyasāra: Hindi anuvāda sahita. Delhi: Pañcolī Pustakamālā Prakāśana Samiti, 1986.

Siddhāntamuktāvalī. Catalogued under the title Hațhayogapradīpikā. Ms. no. $675^{6}$, Rajasthan Oriental Research Institute, Jodhpur.

Hațhatattvakaumudī. See Gharote et al. 2007.

Hațhapradīpikā. Swami Digambaraji and Pt. Raghunatha Shastri Kokaje, eds. Hațhapradīpikā of Svātmārāma. Lonavla: Kaivalyadhama S.M.Y.M. Samiti, 1998.

Hațhapradīpikā. K. Kunjunni Raja, ed. Hațapradīpikā of Svātmārāma with the Commentary Jyotsnā Brahmānanda. Madras: Adyar Library and Research Centre, $1972 .{ }^{71}$ Hațhapradīpikā (with 10 chapters). See Gharote et al. 2006.

Hațhayogamañjarī. Hatha Yoga Manjari. Lonavla: Kaivalyadhama S.M.Y.M. Samiti, 2006.

Hațharatnāvalī. See Gharote et al. 2002.

Hațhasanketacandrikā. Ms. No. B22o, Oriental Research Institute, University of Mysore. Hațhasañketacandrikā. Ms. No. 2244, Man Singh Pustak Prakash Library, Jodhpur.

71 Verse numbers are cited from this edition. 
Hațhasaṃhitā. Paṃ. Nārāyaṇarādha Agnihotrī, ed. Haṭhayoga Saṃhitā, Bhāṣānuvāda sahita. Varanasi: Śrībhāratadharma Press, 1921.

Hațhābhyāsapaddhati. Catalogued under the title Asanabandha. Ms. No. 46/440, Bhārat Itihās Samśodhak Maṇḍal, Pune.

\section{Secondary Sources}

Birch, Jason. 2013. The Amanaska: King of All Yogas. A Critical Edition and Annotated Translation with a Monographic Introduction. Ph.D. thesis, University of Oxford.

Birch, Jason. 2014. "Rājayoga: The Reincarnations of the King of all Yogas." International Journal of Hindu Studies 17, 3 (2013): 401-444.

Birch, Jason. 2015. "The Yogatārāvalī and the Hidden History of Yoga." Nāmarūpa 2o: 4-13. https://www.academia.edu/12099338/ (accessed 23 December 2017).

Birch, Jason. 2018. “The Proliferation of Āsana in Late Mediaeval India." In Yoga in Transformation: Historical and Contemporary Perspectives on a Global Phenomenon, edited by Karl Baier, Philipp A. Maas and Karin Preisendanz, 101-18o. Göttingen: V\&R Unipress (Vienna University Press).

Birch, Jason. 2018a. "Premodern Yoga and Āyurveda: Preliminary Remarks on their Shared Terminology, Theory and Praxis." History of Science in South Asia 6: 1-83. doi: 10.18732/hssa.v6io.25.

Birch, Jason. 2019. "The Amaraughaprabodha: New Evidence on the Manuscript Transmission of an Early Work on Hațha-and Rājayoga." Journal of Indian Philos 47: 947-977. doi: 10.1007/s10781-019-09401-5.

Birch, Jason. Forthcoming. "The Confluence of Hațhayoga, Tapas and Modern Postural Practice: Distinct Regional Collections of Āsanas on the Eve of Colonialism." Journal of Yoga Studies.

Birch, Jason and Singleton, Mark. 2019. "The Yoga of the Hațhābhyāsapaddhati: Hațhayoga on the Cusp of Modernity." Journal of Yoga Studies 2: 1-69. doi: https://doi.org/ 10.3400o/JoYS.2O19.V2

Bouy, Christian. 1994. Les Nātha-Yogin et Les Upaniṣads. Paris: Diffusion De Boccard.

Bühnemann, Gudrun. 2007. Eighty-four Asanas in Yoga: A Survey of Traditions (with Illustrations). New Delhi: D.K. Printworld.

De Michelis, Elizabeth. 2004. A History of Modern Yoga: Patañjali and Western Esotericism. London: Continuum.

Gharote, M.L. 1999. See Jogapradīpyakā.

Gharote, M.L. and Jha, V.K. 2002. Yuktabhavadeva of Bhavadeva Miśra. Lonavla: Lonavla Yoga Institute.

Gharote, M.L. and P. Devnath. 2006. Hațhapradīpikā (with 10 Chapters) of Svātmārāma: with Yogaprakāśikā, a Commentary by Bālakrșṇa. Lonavla: Lonavla Yoga Institute.

Gharote, M.L., P. Devnath, and V.K. Jha. 2002a. Hațharatnāvalī of Śrīnivāsayogī. Lonavla: Lonavla Yoga Institute. 
Gharote, M.L. 2007. Hațhatattvakaumudī: A Treatise on Hațhayoga by Sundaradeva. Lonavla: Lonavla Yoga Institute.

Gharote, M.L., Jha V.K., Devnath, P., and Sakhalkar, S.B. 2006a. Encyclopaedia of Traditional Asanas. Lonavla: Lonavla Yoga Institute.

Harshe, R.G. 197o. Satkarmasangrahaḥ. R.G. Lonavla: Yoga-Mīmāmsā Prakāśana.

Isaacson, Harunaga and Sferra, Francesco. 2014. The Sekanirdeśa of Maitreyanātha (Advayavajra) with the Sekanirdeśapañjikā of Rāmapāla: Critical Edition of the Sanskrit and Tibetan Texts with English Translation and Reproduction of the MSs. Napoli: Università degli studi di Napoli "L' Orientale."

Kuvalayananda, Swami. 1933 [1931]. Asanas. Revised edition. Bombay: Popular Prakashan.

Mallik, Kalyani. 1954. Siddha-Siddhānta-Paddhati and Other Works of the Nātha Yogīs. Pune: Poona Oriental Book House.

Mallinson, James. 2004. The Gheranda Samhitā: The Original Sanskrit and an English Translation. Woodstock: YogaVidya.com.

Mallinson, James. 2014. “The Yogīs' Latest Trick." Journal of the Royal Asiatic Society of Great Britain \& Ireland 24 (1): 165-180.

Mallinson, James. 2016. "Śāktism and Hațhayoga." In Goddess Traditions in Tantric Hinduism: History, Practice and Doctrine, edited by Bjarne Wernicke Olesen, 109-140. Oxford: Routledge.

Mallinson, James. 2020. "The Amrtasiddhi: Hațayoga's Tantric Buddhist Source Text." In Śaivism and the Tantric Traditions: Essays in Honour of Alexis G.J.S. Sanderson, edited by Dominic Goodall, Shaman Hatley, Harunaga Isaacson, and Srilata Raman. Leiden: Brill.

Mallinson, James. Forthcoming, 2020. "Early Hațhayoga." In Religious Practice, The [Oxford] History to Hinduism, edited by Gavin Flood. Oxford: Oxford University Press.

Powell, Seth. 2018. "Etched in Stone: Sixteenth-century Visual and Material Evidence of Śaiva Ascetics and Yogis in Complex Non-seated Āsanas at Vijayanagara." Journal of Yoga Studies 1: 45-106. https://journalofyogastudies.org/index.php/JoYS/article/ view/2018.v1.Powell.EtchedinStone. Accessed 14 November 2019.

Sanderson, Alexis. 2001. "History through Textual Criticism in the study of Śaivism, the Pañcarātra and the Buddhist Yoginītantras." In Les Sources et le temps. Sources and Time, edited by F. Grimal, 1-47. Publications du département d'Indologie 91. Pondicherry: Institut Français de Pondichéry/ École française d'ExtrêmeOrient.

Sanderson, Alexis. 2007. "The Śaiva Exegesis of Kashmir." In Mélanges tantriques à la mémoire d'Hélène Brunner/Tantric Studies in Memory of Hélène Brunner, edited by Dominic Goodall and André Padoux, 231-442, 551-582 (bibliography). Pondicherry: Institut Français de Pondichéry/École française d'Extrême-Orient 
Sanderson, Alexis. 2014. "The Śaiva Literature." Journal of Indological Studies (Kyoto) 24 \& 25 (2012-2013): 1-113.

Sarde, Vijaya. 2015. "Archaeological Signatures of the Nath Cult: A Study of the Yogic Postures and Rituals Depicted on the Brahmanath Temple at Parunde, District Pune." Journal of Multidisciplinary Studies in Archaeology, 3: 232-254.

Sarde, Vijaya. 2017. “'Yoga on Stone': Sculptural Representation of Yoga on Mahuḍi Gate at Dabhoī in Gujarāt." Journal of Multidisciplinary Studies in Archaeology 5: 656-675.

Singleton, Mark. 2010. Yoga Body: The Origins of Modern Posture Practice. New York: Oxford University Press.

Sjoman, Norman. 1996. The Yoga Tradition of the Mysore Palace. New Delhi: Abhinav Publications.

Śrīkṛṣnavallabhācārya. 2001. śrìmanmaharșipravarapatan̂jalipraṇitam yogadarśanam śrīmaddārśanikapañcānanașa d̦arśanācāryanavyanyāyāeārya-sān்khyayogaved $\bar{a}-$ ntamīmāmsātērthapaṇditaśrīkrșṇavallabhācāryaviracitena vedāntatīrthasāṅkhyayogaratnapaṇ̣̂itaśríśvetavaikuṇthaśāstrisvāminārāyaṇa-samśodhitena bhāṣena sahitam tathā tarkavedāntamīmāmsāsāinkhyayoga-tīrthapanditaśrīnārāyanacaraṇaśāstrīsvāminārāyaṇasamśodhitena - paṇịtaśrīkrșnavallabhācāryasvāmi-nārāyanạviracitena paṇditapravarabhojarājakrtarājamārtāṇ̣̂ākhyavrtteh kiraṇena samanvitam. Varanasi: Caukhambā Vidyābhavana, 2001.

Thangaswami, R. 1980. Advaita-Vedanta Literature: A Bibliographical Survey. Madras: University of Madras. 